\title{
Tourist Attraction and Tourist Facilities Intentions to Visitor Satisfaction: Case of Sindang Barang Cultural Village
}

\author{
Maidar Simanihuruk \\ Sekolah Tinggi Pariwisata Bogor \\ Corresponding author: meydar_bj@yahoo.co.id
}

\begin{abstract}
ARTICLE INFO
Received

25 June 2019

Accepted

04 September 2019

Available online

30 September 2019
\end{abstract}

The tourist attraction and tourist facilities provided at the Sindang Barang Cultural Village have a positive influence and significantly contributed to visitor satisfaction, which can attract tourists and visitors to come to this place. The research was conducted at the Sindang Barang Cultural Village. The purpose of this study is to determine the impact of tourist attraction and tourist facilities on visitor satisfaction at the Sindang Barang Cultural Village. The Method of research used is quantitative methods in order to obtain more comprehensive, valid, reliable, and objective data. The sample consists of 107 visitors who visited the Sindang Barang Cultural Village. The factor and regression analysis were used for the data analysis. The results of the study showed that tourist attraction significantly contributed to the visitors' satisfaction $(t=10.180>t$ table with a significance of $0.000(\rho<0.05)$. Tourist facilities significantly contributed to visitors' satisfaction ( $\mathrm{t}=4,082>\mathrm{t}$ table with a significance of $0.000(\rho<0.05)$. The tourist attraction and tourist facilities have a significant effect simultaneously on Visitors' satisfaction $(\mathrm{F}=149.205>\mathrm{F}$ table with a significance of $0.000<0.05$. Tourist attraction at the Sindang Barang Cultural Village has a dominant influence in influencing visitor satisfaction with the uniqueness and characteristics of Sunda Tradition Ritual Tourist Attraction which is the hallmark of the Sindang Barang Cultural Village. The Tourist facilities show that this variable is a variable that affects visitor satisfaction where the facilities available for the information center are still not fully available. The author makes a suggestion, recommend paying more attention and developing facilities that provide complete information about the Sindang Barang Cultural Village.

Keywords: Tourist Attraction, Tourist Facilities, Visitor Satisfaction, Cultural Village, Sindang Barang 


\section{INTRODUCTION}

\section{Background}

Indonesia is a country with different potentials and resources, meaning that it has a lot of opportunities through which it can be developed into a country with tourism industry. In this way, it can earn a lot of foreign exchange which can be used for funding the local, regional and national development (Suryawardani, Purnami, \& Suamba, 2018).

The development of tourist village is strongly influenced by the institutional aspect, the object and the tourist attraction, as well as the means of tourism infrastructure (Damayanti, Soeaidy, \& Ribawanto, 2014; Parmawati, Saktiawan, Wibowo, \& Kurnianto, 2018). There are many tourism objects chosen by tourists. There is a part of the tourists who love natural, cultural, and even artificial objects. Indonesia is a country which has various tourism objects because of its enormous cultures, values, beliefs, weathers, tribes, and so forth. Thus, many tourists travel to Indonesia. Tourism objects and attractions are a form of a facility which can attract tourists and visitors to come to a certain area and place. Without attractions, a place will be difficult to be called as a tourism object.

A tourism product must have several aspects such as attractiveness, maintainability, ease of use and in particular, a product must satisfy consumer desires and be able to fulfill all consumer expectations of a product (Kotler, 2011). Tourism products are places that have attraction as a supporting factor as attracting tourists to visit the tour and have adequate facilities such as access to travel, recreation and many things that make tourists interested in coming to the place.

One part of the attraction destination is the cultural tourist attraction that encompasses cultural villages. Bogor Regency has a cultural village that has a variety of Sundanese arts and culture, history and Sundanese beliefs and customs, a natural rural place and has a place to stay or lodging to give a natural impression for tourists who visit. Bogor as one of the third largest cities in Indonesia is rich in a variety of tourism products, both natural and environmental conservation, Agro tourism and cultural tourism. This has become an attraction for both domestic and foreign tourists to come to visit the city that has the nickname of this city of rain.

Sindang Barang Cultural Village located in Bogor Regency, part of the West Java provinces, Indonesia, which there are still holding various cultural heritages inherited from the Kingdom of Pajajaran. In addition to this time, the Sindang Barang Cultural Village still e-ISSN: 2407-392X. p-ISSN: 2541-0857 
revitalizes Sundanese art and has to continue to strive to have uniqueness and special attraction so as to attract interest to visit because one component of tourism products is the attraction.

Facilities constitute facilities and infrastructure that support the operation of tourism objects to accommodate all the needs of tourists, not directly encourage growth but develop at the same time or after developing attractions (Spillane, 1994; Rosita, Marhanah, \& Wahadi, 2016).

To attract tourists to visit a tourist attraction, tourism objects must have attractive tourist attractions and adequate facilities to support the needs of tourists. If tourists feel comfortable because the facilities available are adequate and tourism objects are attractive, the expectations of tourists when visiting will be fulfilled when they visit. This will lead to a sense of satisfaction because their expectations are met. The tourist attraction is supported by facilities can also increase interest and tourist loyalty (Zaenuri, 2012).

\section{Research Objectives}

This current study was intended to:

1. Analyze the effect of the dimension of tourist attraction (what to see, what to do, what to buy, where to stay, and what to arrive) on the satisfaction of the http://ojs.unud.ac.id/index.php/eot visitors visiting the Sindang Barang Cultural Village.

2. Analyze the effect of the dimension of tourist facilities (accommodation unit, restaurant, activity facilities, and information service) on the satisfaction of the visitors visiting the Sindang Barang Cultural Village.

3. Analyze the effect of the dimension of tourist attraction and tourist facilities simultaneously on the satisfaction of the visitors visiting the Sindang Barang Cultural Village

\section{LITERATURE REVIEW}

\section{Tourist Attraction}

A tourist attraction can be visited by tourists has to meet the conditions for the development of the area (Suryadana \& Octavia, 2015). These conditions are (1) What to see. In these places there must be objects and tourist attractions that are different from those owned by other regions. The area must have special attractions and cultural attractions that can be used as "entertainment" for tourists. What to see includes natural scenery, activities, arts and tourist attractions. (2) What to do. In this place, in addition to many that can be seen and witnessed, activities and recreational facilities must e-ISSN: 2407-392X. p-ISSN: 2541-0857 
be provided that can make tourists feel at home for a long time. (3) What to buy. Tourist destinations should be available for shopping facilities, especially souvenirs and folk handicrafts as souvenirs. (4) What to arrive. This includes accessibility, how visitor can visit the tourist attraction, what vehicles will be used and how long to arrive at the tourist destination. (5) Where to stay. How tourists will stay for a while on vacation, needed lodging either star hotels or nonstarred hotels and so on.

A tourist attraction that attracts tourists is hospitality. The hospitality of an area is the general feeling of welcome that tourists receive while visiting the area. People do not want to go where they do not feel welcome (Mill, 1990; Suryadana \& Octavia, 2015). Tourists are interested in visiting a place if there is a phenomenon that motivates them. The attractiveness of one place could create a certain influence on potential tourists (Subhiksu, Ardika, Darma Putra, \& Madiun, 2014)

\section{Tourist Facilities}

Tourist facilities are all facilities whose function meets the needs of tourists who temporarily stay in the tourist destinations they visit, where they can relax and enjoy and participate in activities available in the tourist destination (Yoeti, http://ojs.unud.ac.id/index.php/eot
2003; Sulistiyana, 2015). The tourists will come and visit again if the facilities are available who can fulfill all their needs while enjoying tourist attraction. The existence of these facilities is also expected to make tourists feel more comfortable and stay longer and provide a good impression on the tourist attraction which they visit (Zaenuri, 2012). According to (Yoeti, 2003), the components of tourist facilities are (1) accommodation unit, (2) restaurant, (3) outdoor activity facilities, (4) art activity facilities, and (5) information service).

It can be concluded that tourism facilities are the convenience of visitors to enjoy, feel the comfort that has been provided by a tourist attraction that has facilities in order to satisfy or achieve the satisfaction of visitors to a tourist destination.

\section{Visitor Satisfaction}

Satisfaction comes when experiences go beyond expectations, while dissatisfaction arises when experiences fall short of expectations (Park, Hwang, Lee, $\&$ Heo, 2018). Tourism satisfaction is the outcome of interactions between a real experience and the prepositional expectations of the tourists participating in tourism-related activities (Pizam, Neumann, \& Reichel, 1978; Park, Hwang, Lee, \& Heo, 2018). Satisfaction is a e-ISSN: 2407-392X. p-ISSN: 2541-0857 
function of the closeness between expectation and the product's perceived performance. (Kotler \& Keller, Marketing Management, 2012). Satisfaction is a feeling of pleasure or disappointment that someone appears after comparing the performance of the product that is thought of the performance or expected results. If the performance of a product meets or exceeds expectations of tourists it will create a sense of satisfaction in every tourist, whereas if the product performance is below expectations, someone will feel dissatisfied and disappointed.

The consumer satisfaction is an overall attitude shown consumers for goods or services after they obtain and use and it is an evaluative assessment postelection caused by the selection of special purchase and experience of using the goods or services ((Mowen \& Minor, 2002; Manulang, Bendesa, \& Darma Putra, 2015). Factors of boosting customer satisfaction consist of: (1) product quality: Customers will feel satisfied after buying or using products and services that are in line with expectations of good quality, (2) price: usually affordable prices with good product quality will be of greater value to create customer satisfaction, (3) service quality: to satisfy customers, a company should first improve services that are as maximum as possible given to customers and always evaluate services that have http://ojs.unud.ac.id/index.php/eot been given directly either by providing product knowledge training to all employees or how to deal with customer complaints correctly, and (4) easiness: ease and comfort in reaching tourist destinations can affect customer satisfaction factors (Irawan, 2009; Suhaji, 2012).

\section{METHODOLOGY}

\section{Research Location and Time}

This study was conducted at the Sindang Barang Cultural Village located in Desa Pasireurih, Kecamatan Taman Sari, Bogor Regency for four months, from March 2018 to July 2018, and they were required to cross as the response of which best described their level of agreement within each of the questionnaire items. Their participation was voluntary and thus leads to no response bias.

\section{Data Collecting}

Both the qualitative and quantitative data were used in the current study. The data were obtained from both the primary and secondary data sources. The data were collected through the library research and field research (observation, direct interview, questionnaire, and documentation). 
Research Population and Samples

The population in this study included all the visitors who visited the Sindang Barang Cultural Village. The sample consists of 107 respondents utilizing non-probability sampling of purposive sampling technique that allows the researcher to not giving equal opportunities to all elements of the population to be selected as a respondent. Of these, 107 responses were deemed useful and used in the data analysis with a valid response rate of 90 percent.

\section{Variables and Data Analysis}

The completed and structured close-ended questionnaires were coded and keyed in Statistical Package for Social Sciences (SPSS) computer program version 22 and descriptive analysis such as means, standard deviation, and correlation analysis was performed. Next, further investigation using hierarchical regression analysis was executed to assess the relationship between a set of two independent variables $\left(\mathrm{X}_{1}\right.$ and $\left.\mathrm{X}_{2}\right)$ and the dependent variable $(Y)$, controlling the effect of a different set of independent variables: Tourist attraction $\left(\mathrm{X}_{1}\right)$ and tourist facilities $\left(\mathrm{X}_{2}\right)$ on the dependent variable: visitor satisfaction $(\mathrm{Y})$, which thereafter could furnish empirical findings in supporting the outlined research objectives.

\section{Demographic Characteristics of Respondents}

In table 1 depicts the respondents' demographic characteristics of respondent. Male respondents made up 44.9 percent of the sample while females made up 55.1 percent. The respondents who come to Sindang Barang Culture Village are dominated aged 20-25 years (72.9 percent) because of young age who have a lot of free time to walk compared to the adult age (usually have a permanent job). This was followed by 47.7 percent of them are students and the young employee made up 32.7 percent. The majority of respondents (75,5 percent) come from Bogor and respondents (80.4 percent) specified that they have been visited at Sindang Barang Culture Village 1-2 times a year. This was followed by 12.1 percent of them who only visit 3-4 times a year. For monthly income, 32.7 percent of the respondents are the employee who has revenue IDR 3 5 million and 30.8 percent respondents are students who spent less than IDR 1 million per month. For choosing considerations, respondents made up 52.3 percent because of the diversity of tourist attractions at Sindang Barang Culture Village and they get information about the Sindang Barang Culture Village made up 45.8 percent are obtained from friends/relatives at $45.8 \%$ 
and these number of respondents who are young, where the youth is a time of group life, togetherness, and friendship provides new information, it seems that there is a Sindang Barang Culture Village. For their motivation to come to Sindang Barang Cultural Village for 42.1 percent relaxation purposes are employees. Relaxation for a number of employees to calm down, enjoy the beauty of nature, find a new place that is more comfortable, and does new activities that create peace in the Sindang Barang Cultural Village. Meanwhile, many respondents who come to the Sindang Barang Cultural Village also aim to educate with the results of 40.2 percent due to a large number of students and students who wish to learn about the Sundanese culture.

\section{Reliability Analysis}

Reliability refers to a sense that the instrument used in research to obtain the desired information can be trusted (reliably) as a data collection tool and able to reveal actual information in the field. The reliability test method used is the Cronbach's Alpha method, construct is considered reliable if the Alpha coefficient is> 0.70 (Sugiarto, Hendratono, \& Djoko, 2015). The reading of Cronbach's $\alpha$ for all the variables as described in Table 2 exceeds the criterion of 0.70 , indicating the survey instrument is reliable to measure all constructs consistently and is free from random error.

Table 1. The Distribution of Demographic Characteristics

\begin{tabular}{|c|c|c|c|c|c|}
\hline \multicolumn{6}{|c|}{ Demographic Characteristics } \\
\hline A. Gender & $\boldsymbol{F}$ & $\%$ & F. Monthly Income & $\boldsymbol{F}$ & $\%$ \\
\hline Male & 48 & 44.9 & $<$ IDR 1000000 & 33 & 30.8 \\
\hline Female & 59 & 55.1 & IDR $1000000-3000000$ & 22 & 20.6 \\
\hline & & & IDR $3000000-5000000$ & 35 & 32.7 \\
\hline & & & $>$ IDR 5000000 & 17 & 15.9 \\
\hline B. Age & $\boldsymbol{F}$ & $\%$ & G. Frequency of Visit & $\boldsymbol{F}$ & $\%$ \\
\hline $14-19$ & 9 & 8.4 & $1-2$ & 86 & 80.4 \\
\hline $20-25$ & 78 & 72.9 & $3-4$ & 13 & 12.1 \\
\hline $26-34$ & 9 & 8.4 & $5-6$ & 2 & 1.9 \\
\hline $35-43$ & 11 & 10.3 & $>6$ & 6 & 5.6 \\
\hline $\begin{array}{l}\text { C. Residential } \\
\text { Area } \\
\end{array}$ & $\boldsymbol{F}$ & $\%$ & $\begin{array}{l}\text { H. Choosing } \\
\text { Consideration }\end{array}$ & $\boldsymbol{F}$ & $\%$ \\
\hline Bogor & 81 & 75.7 & Diversity of Tourist Attractions & 56 & 52.3 \\
\hline Bandung & 1 & 9 & Services provided & 8 & 7.5 \\
\hline Jakarta & 12 & 11.2 & Easy to reach location & 16 & 15.0 \\
\hline Depok & 3 & 2.8 & Ticket Prices / Discounts & 3 & 2.8 \\
\hline Sukabumi & 2 & 1.9 & Place Comfort & 14 & 13.1 \\
\hline Others & 8 & 7.5 & Others & 10 & 9.3 \\
\hline D. Education & $\boldsymbol{F}$ & $\%$ & I. Source of Information & $\boldsymbol{F}$ & $\%$ \\
\hline High School & 42 & 39.3 & Family / Couples Member & 17 & 15.9 \\
\hline Academic & 30 & 28.0 & Friends / Relatives & 49 & 45.8 \\
\hline University & 29 & 27.1 & Social Media/Advertising & 30 & 28.0 \\
\hline $\begin{array}{l}\text { High Degree/ } \\
\text { Doctoral }\end{array}$ & 6 & 5.6 & Others & 11 & 10.3 \\
\hline E. Occupation & $\boldsymbol{F}$ & $\%$ & J. Motivation & $\boldsymbol{F}$ & $\%$ \\
\hline Student & 51 & 47.7 & Relaxation & 45 & 42.1 \\
\hline Employee & 35 & 32.7 & Nostalgia & 5 & 4.7 \\
\hline Gov. Empl & 1 & .9 & Education & 43 & 40.2 \\
\hline Entrepreneur & 9 & 8.4 & Others & 14 & 13.1 \\
\hline Others & 11 & 10.3 & & & \\
\hline TOTAL & 107 & 100 & TOTAL & 107 & 100 \\
\hline
\end{tabular}

Source: The Processed Primary Data (2018) 
Table 2. Reliability Analysis

\begin{tabular}{lcc}
\hline Variables & Number of Items & Cronbach's Alpha \\
\hline Tourist & 10 & .849 \\
Attraction & & \\
Tourist & 5 & .885 \\
Facilities & & \\
Visitor & 13 & .920 \\
Satisfaction & &
\end{tabular}

Source: The Processed Primary Data (2018)

\section{Descriptive statistics}

The descriptive statistics for respondent response of the effects of tourist attraction and tourist facilities on visitor satisfaction is presented in Table 3 .
The multi-item statements are designed for a five-point Likert scale ranging from 1 (strongly disagree) to 5 (strongly agree). As seen in table 3 above, the highest mean value is on WS2 indicator statement which is at an average of 4.28 which means that respondents agree that The Sindang Barang Cultural Village has learning activities and recognizes Sundanese Cultural Arts (learning the history of Indigenous Village, learning farming, learning to dance and learning to play traditional musical instruments).

Table 3. Respondent Response of The Effects of Tourist Attraction and Tourist Facilities on Visitor Satisfaction

\begin{tabular}{llll}
\hline Variable: Tourist Attraction & Labels & Means & SD \\
\hline Have natural scenery beautiful & WS1 & 4.16 & .870 \\
\hline $\begin{array}{l}\text { Having learning activities and } \\
\text { know Sundanese art }\end{array}$ & WS2 & 4.28 & .775 \\
\hline $\begin{array}{l}\text { Unique and unique Attractions } \\
\text { Tradition Rituals Sunda 'Serentaun }\end{array}$ & WS3 & 4.18 & .799 \\
\hline $\begin{array}{l}\text { Have activities and facilities } \\
\text { recreation }\end{array}$ & WD1 & 3.91 & .807 \\
\hline $\begin{array}{l}\text { Have facilities for shop for } \\
\text { souvenirs and items folk crafts }\end{array}$ & WB1 & 3.63 & .937 \\
\hline Have lodging & WS1 & 3.87 & .814 \\
\hline Adequate infrastructure and facilities & WS2 & 3.56 & .838 \\
\hline Easiness Access to locations & WA1 & 3.19 & .963 \\
\hline Security guaranteed & HO1 & 3.74 & .862 \\
\hline Society and employees friendly \& polite & HO2 & 4.08 & .881 \\
\hline & & & \\
\hline & & & Means \\
\hline Variable: Tourist Facilities & Labels & SD \\
\hline Homestay facilities & HS1 & 3.63 & .853 \\
\hline Serving Drinks \& Buffet Food & DF1 & 3.76 & .834 \\
\hline Facilities for Outdoor Activities & OA1 & 3.90 & .890 \\
\hline Facilities for Dance Course & DC1 & 3.92 & .870 \\
\hline Information Service & IS1 & 3.48 & .975 \\
\hline & & & \\
\hline
\end{tabular}


and the community who are friendly and

\begin{tabular}{|c|c|c|c|}
\hline Variable:Visitor Satisfaction & Labels & Means & SD \\
\hline $\begin{array}{l}\text { Satisfaction on Tourist Attractions } \\
\text { at Sindang Barang Cultural Village }\end{array}$ & CS1 & 4.07 & .768 \\
\hline $\begin{array}{l}\text { Satisfaction with Accessibility } \\
\text { towards tourist sites }\end{array}$ & $\mathrm{CS} 2$ & 3.36 & .934 \\
\hline $\begin{array}{l}\text { Satisfaction with the facilities } \\
\text { in Sindang Barang }\end{array}$ & CS3 & 3.75 & .859 \\
\hline Price of admission & CS4 & 3.64 & .756 \\
\hline Promotion of Promo Prices/Discount & CS5 & 3.82 & .969 \\
\hline Alertness to serve traveler & CS6 & 3.79 & .855 \\
\hline $\begin{array}{l}\text { Good communicate and explain } \\
\text { information to tourist }\end{array}$ & CS7 & 3.95 & .745 \\
\hline $\begin{array}{l}\text { Accuracy and suitability time } \\
\text { in tourist attractions }\end{array}$ & CS8 & 3.73 & .784 \\
\hline Handling Complaint & CS9 & 3.74 & .839 \\
\hline $\begin{array}{l}\text { Have knowledge about all } \\
\text { tourist attractions }\end{array}$ & CS10 & 3.85 & .867 \\
\hline $\begin{array}{l}\text { Have hospitality and politeness } \\
\text { in serving visitor }\end{array}$ & CS11 & 4.03 & .783 \\
\hline Willingness to help & CS12 & 3.93 & .839 \\
\hline $\begin{array}{l}\text { Ease of reaching all tourist attractions } \\
\text { all tourist attractions }\end{array}$ & CS13 & 3.92 & .814 \\
\hline
\end{tabular}

Whereas the lowest mean value is on the statement of tourist attraction statement WA1 which is at an average of 3.19, which means that neutral respondents state that access to the location to the Sindang Barang Cultural Village is easy. Overall respondents' perceptions of Tourist Attraction in Sindang Barang Cultural Village found that the dominant respondents agreed that meant that tourist attraction in Sindang Barang Cultural Village had special attractions and cultural attractions that could be seen and witnessed, lodging like home stay and hospitality from employees
The highest mean value is on Tourism Facilities DC1 indicator statement which is on average 3.92 which means respondents almost all agree that Sindang Barang Cultural Village provides facilities for short training such as Jaipong, Pencak silat and playing angklung and well prepared. While the lowest mean value is on the Tourism Facilities IS1 indicator statement which is at an average of 3.48 which means that neutral respondents stated that the Goods Session Culture Village has not provided facilities for a complete information center. 
For Visitor Satisfaction, the highest mean value is in the indicator of the statement of CS1, which is on average 4.07, which means that respondents almost all agree that they are satisfied with Tourist Attractions in Sindang Barang Cultural Village. While the lowest mean value is in the indicator of the statement of CS2 which is at an average of 3.36 which means that neutral respondents expressed satisfaction with access to the location to the Goods Session Culture Village. Respondents' perceptions of Visitor Satisfaction in Sindang Barang Cultural Village found that the dominant respondents agreed that meant that the tourists who had visited were satisfied with the quality of tourism products, prices, quality of service and ease in reaching all tourist attractions provided in Kampung Sindang Barang Culture Village.

The standard deviation value has a value close to 1 (whole number) which is between 0.775 to $0.963,0.834$ to 0.975 and 0.745 to 0.969 which means that the diversity of respondents gives answers large enough and not homogeneous in providing answers to tourist attraction which means that all answers given by respondents vary.

\section{Results of the Regression Analysis}

Simple Correlation Analysis is used to determine the relationship between one independent variable to the dependent variable. Determination analysis in simple regression is used to determine the percentage contribution of the influence of the independent variable on the dependent variable (Sugiyono, 2016).

Table 4. The Effects of Tourist Attraction on Visitor Satisfaction and Tourist Facilities on Visitor Satisfaction

\begin{tabular}{ccccc}
\hline Variable & $\mathbf{R}$ & $\begin{array}{c}\mathbf{R} \\
\text { Square }\end{array}$ & $\begin{array}{c}\text { Adjusted } \\
\mathbf{R} \\
\text { Square }\end{array}$ & $\begin{array}{c}\text { Std. } \\
\text { Error of } \\
\text { the } \\
\text { Estimate }\end{array}$ \\
\hline $\mathrm{X}_{1}$ & .837 & .700 & .697 & 4.256 \\
\hline $\mathrm{X}_{2}$ & .696 & .484 & .479 & 5.583 \\
\hline \multicolumn{4}{l}{ Source: The Processed Primary Data (2018) }
\end{tabular}

As seen in table 4, correlation among tourist attraction on visitor satisfaction and tourist facilities on visitor satisfaction are seen. The $\mathrm{R}$ number is 0.837, this shows that there is a very strong relationship between tourist attraction on visitor satisfaction and the $\mathrm{R}$ number is 0.696 , this shows that there is a strong relationship between tourist facilities on visitor satisfaction. The determination coefficient is obtained by R2 (R Square) by 0.700 for $\mathrm{X}_{1}$. This shows that the percentage contribution of the influence of tourist attraction on visitor satisfaction by $70 \%$ while $30 \%$ is influenced by other variables not 
examined. Also for $\mathrm{X}_{2}$, the determination coefficient is obtained by R2 ( $\mathrm{R}$ Square) by 0.484 . This shows that the percentage contribution of the influence of tourist attraction on visitor satisfaction by $48.4 \%$ while $51.6 \%$ is influenced by other variables not examined.

Multiple linear regression analysis is a linear relationship between two or more independent variables with the dependent variable. This analysis is to determine the direction of the relationship between the independent variable and the dependent variable whether each independent variable is positively or negatively related and to predict the value of the dependent variable if the value of the independent variable increases or decreases.

Table 5. The Effects of Tourist Attraction and Tourist Facilities on Visitor Satisfaction

\begin{tabular}{llll}
\hline $\mathbf{R}$ & $\begin{array}{l}\text { R } \\
\text { Square }\end{array}$ & $\begin{array}{l}\text { Adjusted } \\
\text { R Square }\end{array}$ & $\begin{array}{l}\text { Std. Error } \\
\text { of } \\
\text { Estimate }\end{array}$ \\
\hline .861 & .742 & .737 & 3.971 \\
\hline the
\end{tabular}

Source: The Processed Primary Data (2018)

As seen in table 5, correlation among tourist attraction and tourist facilities on visitor satisfaction are seen. The $\mathrm{R}$ number is 0.861 , this shows that there is a very strong relationship between tourist attraction and tourist facilities on visitor satisfaction. The determination coefficient is obtained by R2 (R Square) by $0.742(74.2 \%)$. This shows that the percentage contribution of the influence of independent variables Tourist Attraction and Tourism Facilities on Visitor Satisfaction by $74.2 \%$ while $25.8 \%$ is influenced by other variables not examined.

As indicated in table 6 , the results of multiple linear regression hypotheses testing, $\mathrm{T}$ test and $\mathrm{F}$ test to determine the effect of independent variables (independent) on the fixed variable (dependent).

Table 6. Hypothesis Testing Results

\begin{tabular}{|c|c|c|c|}
\hline Hypothesis & Statement & Score & $\begin{array}{l}\text { Remark } \\
\text { S }\end{array}$ \\
\hline $\mathrm{H}_{1}$ & $\begin{array}{l}\text { Tourist } \\
\text { Attraction } \\
\text { Significant } \\
\text { Effect on } \\
\text { Visitor } \\
\text { Satisfaction }\end{array}$ & $\begin{array}{l}\mathrm{t}= \\
10.180 \\
\mathrm{sig}= \\
0.000\end{array}$ & $\begin{array}{l}\mathrm{H}_{1} \\
\text { accept } \\
\mathrm{H}_{0} \\
\text { reject }\end{array}$ \\
\hline $\mathrm{H}_{2}$ & $\begin{array}{l}\text { Tourist } \\
\text { Facilities } \\
\text { Significant } \\
\text { Effect on } \\
\text { Visitor } \\
\text { Satisfaction }\end{array}$ & $\begin{array}{l}\mathrm{t}= \\
4.082 \\
\text { sig = } \\
0.000\end{array}$ & $\begin{array}{l}\mathrm{H}_{2} \\
\text { accept } \\
\mathrm{H}_{0} \\
\text { reject }\end{array}$ \\
\hline $\mathrm{H}_{3}$ & $\begin{array}{l}\text { Tourist } \\
\text { Attraction } \\
\text { and Tourist } \\
\text { Facilities } \\
\text { Simultaneous } \\
\text { ly Significant } \\
\text { Effect on } \\
\text { Visitor } \\
\text { Satisfaction }\end{array}$ & $\begin{array}{l}F= \\
149.20 \\
5 \\
\text { sig = } \\
0.000\end{array}$ & $\begin{array}{l}\mathrm{H}_{3} \\
\text { accept } \\
\mathrm{H}_{0} \\
\text { reject }\end{array}$ \\
\hline
\end{tabular}

Source: The Processed Primary Data (2018) 
In Table 6, the results of the t-test analysis related to tourist attraction on visitor satisfaction in the Sindang Barang Cultural Village, the $\mathrm{t}$ count $>\mathrm{t}$ table was obtained; $10.180>1.659$ with a significance of $0.000(\rho<0.05)$. The positive $t$ value indicates that the tourist attraction has a direct relationship with visitor satisfaction. So it can be concluded that the tourist attraction has a significant influence on visitor satisfaction. These results indicate that the higher the attractiveness of a tourist object, the greater the satisfaction of tourists visiting.

The results of the t-test analysis related to tourist facilities on visitor satisfaction in the Sindang Barang Cultural Village, the $\mathrm{t}$ count $>\mathrm{t}$ table was obtained; $4,082>1,659$ with a significance of 0.000 $(\rho<0.05)$. The Tourism Facilities has a significant influence on Visitor Satisfaction.

The results of this study indicate that tourist attraction and tourist facilities have a significant effect simultaneously on visitors' satisfaction. Based on the results of the test analysis simultaneously obtained the $\mathrm{F}$ count value is 149.205 with a probability value $(\mathrm{sig})=0.000$. The value of $\mathrm{F}$ is calculated (149.205) $>\mathrm{F}$ table (3.08), and the value of sig. smaller than the 0.05 probability value or $0.000<0.05$.

\section{CONCLUSIONS}

Based on the results of the study, several conclusions can be drawn as follows:

1) The effect of the tourist attraction on the satisfaction of the visitors visiting the Sindang Barang Cultural Village:

The dimension of tourist attraction (what to see, what to do, what to buy, where to stay, and what to arrive) positively and significantly contributed to satisfaction of the visitors visiting the Sindang Barang Cultural Village, meaning that the tourist attraction at the Sindang Barang Cultural Village has special attractions and cultural attractions that can be seen and witnessed, also Hospitality from employees and the community who are friendly and polite. Tourist satisfaction can be created if the tourist attraction offered to give something different and has the characteristics of other tourism objects in general, and can give a deep impression for tourists who have made a visit.

2) The effect of the tourist facilities on the satisfaction of the visitors visiting the Sindang Barang Cultural Village: 
Tourist facilities (accommodation unit, restaurant, activity facilities, and information service) positively and significantly contributed to satisfaction of the visitors visiting the Sindang Barang Cultural Village. The reason for tourists to visit a place or region or country because they are interested in the facilities that can be obtained through the facilities and the assessment of visitors to facilities in a tourist attraction is usually associated with satisfaction after visiting the tourist attraction (Rezki, Djamhur, \& Devi, 2015).

3) The effect of the tourist attraction and tourist facilities simultaneously on the satisfaction of the visitors visiting the Sindang Barang Cultural Village: Tourist attraction and tourist facilities have a positively and significantly contributed to satisfaction of the visitors visiting the Sindang Barang Cultural Village.

\section{SUGGESTIONS}

(Sudiarta, 2015), in his study entitled "Popularity of Tourist Attraction in Bali from the Perspective of Foreign Tourists" found that position tourist attraction can be described with two http://ojs.unud.ac.id/index.php/eot dimensions: one dimension is an attraction that has a lot of similarities and a second dimension is the attraction that has many differences.

The variable tourist attraction at Sindang Barang Cultural Village has a dominant influence in influencing visitor satisfaction by having the uniqueness and characteristics of Sunda 'Tradition Ritual Tourist Attraction which is the hallmark of Sindang Barang Cultural Village, it is necessary for the management to still maintain this tourist attraction with regular return held every year. The continuity of tourist attractions, especially Sundanese traditional attractions 'Serentaun needs to receive support and attention from the Bogor Regency Government, especially the Bogor Regency Culture and Tourism Office because it relates to attention to the preservation of Sundanese culture. It is recommended to pay more attention and develop facilities that provide complete information about the Sindang Barang Cultural Village. Some facilities and infrastructure at the Sindang Barang Culture Village require improvements with not small amounts of funds. Imports have not all been able to cover the maintenance and operational costs of the Sindang Barang Cultural Village, for that there is a need for financial assistance from the Bogor Regency Culture and Tourism Office. 


\section{ACKNOWLEDGEMENT}

The author would like to thank the Bogor School of Tourism (STP Bogor) who has given assistance in the form of finance. The author also thanked the Trisakti School of Tourism (STP Trisakti) who giving the opportunity to the author as a student of STP Trisakti Postgraduate Program 2017/2018 to do Field Research at the Sindang Barang Cultural Village in partial fulfillment of the requirement for the Degree of Master in STP Trisakti.

\section{REFERENCES}

Ajeng, F. N. (2016). Pengaruh Daya Tarik Wisata Terhadap Niat Kunjungan Ulang Wisatawan Dengan Kepuasan Wisatawan Sebagai Variabel Intervening Pada Taman Safari Indonesia Cisarua Bogor. Jurnal Pariwisata 2016, 1-9.

Amelia, R., \& Palupi, S. (2016, September). The Influence of Services Quality to Domestic Tourists' Loyalty through Domestic Tourists' Satisfaction at Mount Bromo Tourism in East Java Indonesia. E-Journal of Tourism, III(2), pp. 81-87.

Damayanti, E., Soeaidy, M., \& Ribawanto. (2014). Strategi Capacity Building Pemerintah Desa Dalam Pengembangan Potensi Kampoeng Ekowisata Berbasis Masyarakat Lokal. Jurnal Administrasi Publik, 2(3), 464-470.

http://ojs.unud.ac.id/index.php/eot
Irawan, H. (2009). Sepuluh Prinsip Kepuasan Pelanggan. Jakarta, DKI Jakarta, Indonesia: Elex Media Komputindo Gramedia .

Kotler, P. (2011). Marketing for Hospitality and Tourism. New Jersey: Pearson Education.

Kotler, P., \& Keller, K. L. (2012). Marketing Management (14 ed.). (K. Bloom, \& E. Scarpa, Eds.) New Jersey, United States of America: Prentice Hall: Pearson.

Manulang, S., Bendesa, I. G., \& Darma Putra, I. N. (2015, March 10). The Effect of Service Quality in International Airport I Gusti Ngurah Rai on Satisfaction, Image, and Tourists Loyalty Who Visited Bali. (I. G. Bendesa, Ed.) EJournal of Tourism, II(1), pp. 9-21.

Mill, R. C. (1990). Tourism: The International Business. Harlow, United Kingdom: Pearson Education Limited.

Mowen, J., \& Minor, M. (2002). Perilaku Konsumen Jilid 1. Jakarta: Erlangga.

Park, S., Hwang, D., Lee, W. S., \& Heo, J. (2018, October 9). Influence of Nostalgia on Authenticity, Satisfaction, and Revisit Intention: The Case of Jidong Mural Alley in Korea. (J. Grahe, Ed.) Internet Resource, p. 6.

Parmawati, R., Saktiawan, Y., Wibowo, F., \& Kurnianto, A. S. (2018, March). Analysis of Village Tourism Development in Sawahan, Trenggalek Regency, Indonesia: A Sustainable Livelihood Approach. E-Journal of Tourism, V(1), pp. 4653.

Pizam, A., Neumann, Y., \& Reichel, A. (1978, July). Dimentions of Tourist Satisfaction With a Destination Area. Annals of Tourism Research, $V(3), 314-322$.

e-ISSN: 2407-392X.p-ISSN: 2541-0857 
Rezki, T. S., Djamhur, H., \& Devi, F. A. (2015, August). Pengaruh Fasilitas Wisata Dan Harga Terhadap Kepuasan Konsumen (Studi Pada Museum Satwa). Jurnal Administrasi Bisnis (JAB), XXV(1), 1-9.

Rosita, Marhanah, S., \& Wahadi, W. H. (2016, April). Pengaruh Fasilitas Wisata dan Kualitas Pelayanan Terhadap Kepuasan Pengunjung di Taman Margasatwa Ragunan Jakarta. (A. H. Galihkusumah, F. Rahmafitria, Rosita, R. M. Wirakusuma, \& G. R. Nurazizah, Eds.) Jurnal Manajemen Resort dan Leisure, XIII(1), 63.

Simanihuruk, M., Mumin, A. T., \& Wulan, S. (2018). The Effect of Tourist Attraction Toward Visitor Satisfaction in Sindang Barang Cultural Village, Bogor Regency. Tourism Research Journal, II(2), pp. 33-44.

Spillane, J. J. (1994). Pariwisata Indonesia. Siasat Ekonomi dan Rekayasa Kebudayaan. Yogyakarta: Kanisius.

Suardana, I. W., Bendesa, I., \& Antara, M. (2014). Satisfaction as Mediators of the Relationship between Motivation and Loyalty of Diving Tourists to Bali. E-Journal of Tourism, I(1), pp. 12-24.

Subhiksu, I. K., Ardika, I. W., Darma Putra, N., \& Madiun, I. N. (2014, September 10). Museums as Cultural Tourism Attractions in Ubud. (I. G. Bendesa, Ed.) EJournal of Tourism, I(2), pp. 114127.

Sudiarta, I. N. (2015). Popularity of Tourist Attraction in Bali from the Perspective of Foreign Tourists. EJournal of Tourism, II(2), pp. 6873.
Sugiarto, P., Hendratono, T., \& Djoko, S. (2015). Metodologi Penelitian Hospitality \& Pariwisata. Tangerang: Matana Publishing.

Sugiyono, P. D. (2016). Metode Penelitian Manajemen (Pendekatan

Kuantitatif, Kualitatif, Kombinasi (Mixed Methods), Penelitian Tindakan (Action Research, dan Penelitian Evaluasi). Bandung: Alfabeta $\mathrm{Cv}$.

Suhaji, I. A. (2012). Faktor-Faktor Yang mempengaruhi Kepuasan Pelanggan Pada UD Pandan Wangi Semarang. Jurnal Kajian Akutansi dan Bisnis, I(1), 1-19.

Sulistiyana, R. T. (2015, August). Pengaruh Fasilitas Wisata Dan Harga Terhadap Kepuasan Konsumen (Studi Pada Museum Satwa). Jurnal Administrasi Bisnis (JAB), $X X V(1), 3$.

Suryadana, M. L., \& Octavia, V. (2015). Pengantar Pemasaran Pariwisata (1st ed.). (D. Handi, Ed.) Bandung: Alfabeta.

Suryawardani, I. O., Purnami, N. A., \& Suamba, I. K. (2018, September). The Effect of the Quality of Services on the Visitor's Satisfaction and Desire to Pay a Revisit to the Bali Pulina Agrotourism. E-Journal of Tourism, V(2), pp 62-71.

Yoeti, O. A. (2003). Tours and Travel Management. Jakarta: Pradnya Paramita.

Zaenuri, M. (2012). Perencanaan Strategis Kepariwisataan Daerah: Konsep dan Aplikasi. Yogyakarta: e-Gov Publishing. 